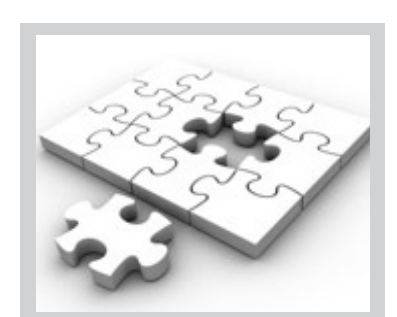

In an effort to facilitate the selection of appropriate peer reviewers for Pythagoras, we ask that you take a moment to update your electronic portfolio on https:// pythagoras.org.za for our files, allowing us better access to your areas of interest and expertise, in order to match reviewers with submitted manuscripts.

If you would like to become a reviewer, please visit the journal website and register as a reviewer.

To access your details on the website, you will need to follow these steps:

1. Log into the online journal at https:// pythagoras.org.za

2. In your 'user home' [https://pythagoras. org.za/index.php/ pythagoras/user] select 'edit my profile' under the heading 'my account' and insert all relevant details, bio statement and reviewing interest(s).

3. It is good practice as a reviewer to update your personal details regularly to ensure contact with you throughout your professional term as reviewer to Pythagoras.

Please do not hesitate to contact us if you require assistance in performing this task.

Publisher: publishing@aosis.co.za

Tel: +27 219752602

Tel: 0861000381

\section{Acknowledgement to reviewers}

The editorial team of Pythagoras recognises the value and importance of the peer reviewer in the overall publication process - not only in shaping the individual manuscript, but also in shaping the credibility and reputation of our journal.

We are committed to the timely publication of all original, innovative contributions submitted for publication. As such, the identification and selection of reviewers who have expertise and interest in the topics appropriate to each manuscript are essential elements in ensuring a timely, productive peer review process.

We would like to take this opportunity to thank all reviewers who participated in shaping this volume of Pythagoras. We appreciate the time taken to perform your review(s) successfully.

$\begin{array}{ll}\text { Alwyn Olivier } & \text { Lyn Webb } \\ \text { André du Plessis } & \text { Marc North } \\ \text { Aneshkumar Maharaj } & \text { Marie Joubert } \\ \text { Anita L. Campbell } & \text { Mdutshekelwa C. Ndlovu } \\ \text { Anthea Roberts } & \text { Michael Murray } \\ \text { Anthony Essien } & \text { Michael D. de Villiers } \\ \text { Belinda Huntley } & \text { Michael K. Mhlolo } \\ \text { Benita P. Nel } & \text { Million Chauraya } \\ \text { Carol Macdonald } & \text { Mohammad F. Gierdien } \\ \text { Caroline Long } & \text { Neil Eddy } \\ \text { Cerenus Pfeiffer } & \text { Nokulunga S. Ndlovu } \\ \text { Deonarain Brijlall } & \text { Patrick Barmby } \\ \text { Duan van der Westhuizen } & \text { Paul Mokilane } \\ \text { Duncan Mhakure } & \text { Piera Biccard } \\ \text { Eunice K. Moru } & \text { Rina Durandt } \\ \text { George Ekol } & \text { Rose S. Maoto } \\ \text { Hamsa Venkatakrishnan } & \text { Sarah Bansilal } \\ \text { Helen Sidiropoulos } & \text { Shaheeda Jaffer } \\ \text { Iben M. Christiansen } & \text { Sheena Rughubar-Reddy } \\ \text { Ifunanya J.A. Ubah } & \text { Tarun K. Tyagi } \\ \text { Ingrid E. Mostert } & \text { Vanessa Scherman } \\ \text { Jacques du Plessis } & \text { Vasuthavan Govender } \\ \text { Joseph Baidoo } & \text { Yip-Cheung Chan } \\ \text { Kabelo Chuene } & \text { Zingiswa M.M. Jojo } \\ \text { Kakoma Luneta } & \text { Zwelithini B. Dhlamini } \\ \text { Karen E. Junqueira } & \end{array}$

Karen E. Junqueira 